\title{
Disease Response Reference Identifier
}

National Cancer Institute

\section{Source}

National Cancer Institute. Disease Response Reference Identifier. NCI Thesaurus. Code C117399.

A sequence of characters used to identify, name, or characterize the disease response reference. 